\title{
OPTIMALISASI USAHA MIKRO MELALUI DISEMINASI PENGOLAHAN CABAI UNTUK MENINGKATKAN PEREKONOMIAN MASYARAKAT DI DESA KERONGKONG
}

\author{
Esty Oktavia ${ }^{1^{*}}$, Susilawati ${ }^{2}$, Aminatun Amalia $^{3}$, Raden Sutriono ${ }^{4}$ \\ ${ }^{1}$ Pendidikan Bahasa Inggris, Fakultas Keguruan dan IImu Pendidikan, Universitas Mataram \\ ${ }^{1}$ Teknologi Pangan, Fakultas Teknologi Pangan dan Agroindustri, Universitas Mataram \\ ${ }^{3}$ Akuntansi, Fakultas Ekonomi dan Bisnis, Universitas Mataram \\ ${ }^{4}$ Jurusan IImu Tanah, Fakultas Pertanian, Universitas Mataram \\ Penulis korespodensi: doeunsup@gmail.com
}

\begin{abstract}
ABSTRAK. Salah satu aspek penunjang kesejahteraan hidup masyarakat yaitu mengelola potensi lokal yang ada di daerahnya. Desa Kerongkong merupakan salah satu desa di Kecamatan Suralaga yang secara demografis memiliki banyak potensi lokal daerah. Potensi terbesar di desa ini yaitu $90 \%$ terletak pada bidang petanian khususnya tanaman Cabai. Meskipun hasil tanaman cabai melimpah, namun warga desa setempat masih belum bisa memanfaatkan cabai menjadi produk yang memiliki nilai jual yang tinggi. $\mathrm{Hal}$ ini disebabkan kurangnya pengetahuan masyarakat tentang hal tersebut. Sehingga salah satu program kerja utama KKN ini yaitu bagaimana cara pengolahan cabai sehingga menghasilkan nilai jual yang tinggi dengan membangun mitra kopeasi dengan ibu-ibu PKK di desa tersebut. Di desa ini sebagian besar masyarakatnya bekerja sebagai petani. Hal ini lah yang mendorong kami untuk melakukan kegiatan pengolahan cabai sebagai potensi desa ini. Disamping itu terdapat beberapa program kerja yang tujuan untuk mempererat silaturrahmi antara mahasiswa dan masyarakat desa.
\end{abstract}

Kata kunci: Potensi Lokal, pengolahan Cabai, Kerongkong.

\section{PENDAHULUAN}

Kebutuhan masyarakat terhadap sayuran dan buah-buahan semakin meningkat. Hal ini bukan hanya karena meningkatnya jumlah penduduk namun juga oleh meningkatnya pengetahuan masyarakat tentang pentingnya gizi yang terkandung dalam sayur dan buah. Sayuran dan buah-buahan termasuk tanaman hortikultura yang mengandung nilai gizi yang tinggi dan merupakan sumber mineral dan vitamin yang sangat dibutuhkan oleh tubuh manusia.

Cabai rawit (Capsicum frutescens,L.) merupakan salah satu tanaman hortikultura dari famili Solanaceae yang memiliki nilai ekonomi tinggi (Cahyono, 2003). Cabai rawit digunakan sebagai bumbu masakan dan bahan. Menurut Rukmana (2002), secara umum buah cabai rawit mengandung zat gizi antara lain lemak, protein, karbohidrat, kalsium, fosfor, besi, vitamin A, B1, B2, C dan senyawa alkaloid seperti capsicin oleoresin, flavanoid dan minyak esensial. Kandungan tersebut banyak dimanfaatkan sebagai bahan bumbu masak, ramuan obat tradisional, industri pangan dan pakan unggas.

Cabai selain berguna sebagai penye- dap masakan,juga mengandung zat-zat gizi yang sangat diperlukan untuk kesehatan manusia. Cabai mengandung protein, lemak, karbohidrat, kalsium $(\mathrm{Ca})$, fosfor $(\mathrm{P})$, besi $(\mathrm{Fe})$, vitamin- vitamin, dan mengan- dung 
senyawa- senyawa alkaloid, seperti capsaicin, flavonoid, dan minyak esensial. Selain itu cabai juga mengandung antiok- sidan yang berfungsi untuk menjaga tubuh dari serangan radikal bebas. Cabai juga mengandung Lasparaginase dan Capsaicin yang berperan sebagai zat anti kanker (Kilham 2006; Bano dan Sivarama- krishnan, 1980).

Selain mempunyai banyak kandungan, buah cabai rawit ini juga mempunyai banyak manfaat terutama sebagai bumbu masakan untuk memberikan sensasi pedas. Selain itu, buah tanaman ini juga berkhasiat untuk menambah nafsu makan, menguatkan kembali tangan dan kaki yang lemas, melegakan hidung tersumbat pada penyakit sinusitis, serta mengobati migrain (sakit kepala sebelah). Sebagai obat luar, cabai rawit juga dapat digunakan untuk mengobati penyakit rematik, sakit perut, dan kedinginan. Selain sebagai bahan makanan dan obat, cabai rawit sering digunakan sebagai tanaman hias disejumlah pekarangan (Tjandra, 2011). Cabai merupakan jenis tubuhan dan buah dengan nama ilmiah Genus Capsicum. Dalam pengolahannya cabai biasa digunakan sebagai bumbu dapur maupun sayuran yang terkenal dengan cita rasa pedasnya dan sangat populer di Asia Tenggara. Akibatnya cabai selalu menjadi pen damping hidangan yang wajib disajikan ketika makan.

Desa Kerongkong merupakan salah satu desa maritim yang manghasilkan cabai terbesar di Lombok Timur. Berdasarkan data statistik desa Kerongkong tahun 2017 tercatat terdapat 2,50 ha tanah yang digunakan untuk menanami cabai dan menghasilkan 12 Ton cabai pertahunnya. Hasil dari perkebunan cabal ini diimport ke berbagai daerah setiap tahunnya. Seeing tercatat sebanyak 242 masyarakat berprofesi sebagai seorang petani dikarenakan hasil cabai yang meluah tersebut. Cabai telah menjadi penghasilan utama bagi para petani dikerongkong. Namun seperti halnya pertanian lainnya, terdapat berbagai masalah yang selalu petani setempat hadapi. Salah satunya adalah meningkatnya harga kargo. Apabila kargo mengalami kenaikkan, harga cabai bisa mencapai Rp. 3000, -

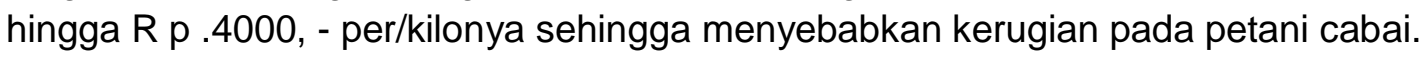

Untuk mengatasi hal ini petani setempat melakukan pengeringan terhadapcabai agar membuat harga cabai naik dipasaran. Hanya saja karena proses pengeringan yang membutuhkan waktu lama dan terkendala oleh berbagai masalah sehingga belum begitu memberikan hasil yang baik bagi petani. Banyaknya cabai yang diproduksi oleh masyarakat setempat setiap tahunnya sangat berpotensi untuk membuat olahan cabai. Seperti yang diketahui bahwa cabai merupakan bumbu yang sangat digemari oleh masyarakat di Lombok khususnya dan di Indonesia umumnya. Sehingga pembuatan olahan cabai ini diperkirakan sangat laris dipasaran.

Begitu banyak olahan yang dapat dibuat dengan bahan utamanya adalah cabai. Salah satu yang sangat digemari adalah sambal cabai. Sambal cabai menjadi pendamping makanan yang sangat khas di Indonesia. Hal ini menyebabkan berbagai daerah di Indonesia memproduksi sambal khas yang sangat laris dipasaran Indonesia hingga ke manca negara. Melihat potensi ini menyebabkan kami membuat sambal cabai khas Kerongkong yang kami sebut sebagai "Sambal Banteng Ngangak". Dengan produk ini kami ingin memperkenalkan kekayaan daerah kerongkong akan cabainya dan membuat produk khas daerah tersebut. Pembuatan produk ini bertujuan pertama untuk membantu petani cabai dalam menyelesaikan permasalahannya dalam memasarkan cabai. Kedua untuk memperkenalkan daerah kerongkong sebagai daerah penghasil cabai terbesar di Lombok timur di pasar Lombok khususnya dan di Indonesia pada umumnya.

Adapun hasil yang diharapkan dari dilakukannya kegiatan ini adalah untuk membantu petani cabai dalam memasarkan hasil tanaman cabainya dalam bentuk produk yang memiliki 
nilai jual yang lebih menguntungkan dipasaran sehingga membantu masyarakat dalam meningkatkan perekonomiannya.

\section{METODE PELAKSANAAN \\ Waktu dan Tempat}

Kegiatan ini dilakukan pada tanggal 12, 26, 27, 28, Februari 2019 desa Kerongkong, Kecamatan Suralaga, Kabupaten Lombok Timur.

\section{Alat dan Bahan}

Alat yang diguanakan pada kegiatan ini adalah kompor, blender, sendok, sutil, penggorengan, piring dan kemasan sambal. Sedangkan bahan yang digunakan pada pembuatan produk ini adalah cabai, tomat, bawang merah, bawang putih, terasi, gula, garam, dan penyedap rasa.

\section{Prosedur Kerja Pembuatan Sambal Banteng Ngangak}

Prosedur cara pembuatan sambal banteng ngangak adalah: 1) sosialisasi program dan pelatihan pembuatan sambal cabai 2) mempersiapkan alat dan bahan, 3) dilakukan pencucian bahan-bahan, 4) haluskan bahan-bahan dalam blender, 5) goreng bahan-bahan yang telah dihaluskan di penggorengan, 6) tiriskan sambal, 7) bungkus sambal dalam botol kemasan, 8) berikan stiker produk untuk mempercantik produk, 9) pendampingan, 10) pemasaran.

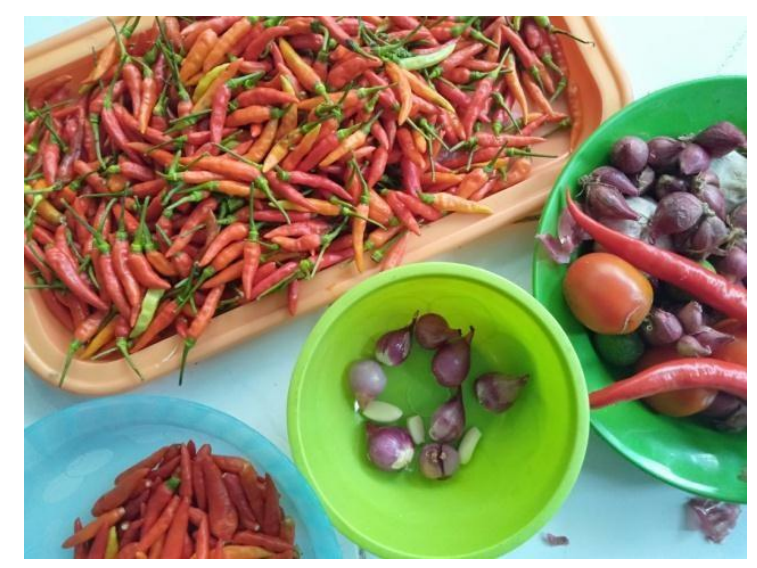

Gambar 1. Bahan baku sambel Banteng Ngangak.

\section{Metode Pengumpulan dan Analisis Data}

Menurut Sugiyono (2013:2) metode penelitian merupakan cara ilmiah untuk mendapatkan data dengan tujuan dan kegunaan tertentu. Untuk itu dilakukan metode pengumpulan data dengan cara melakukan survei menggunakan teknik wawancara terhadap petani-petani cabai yang ada di desa kerongkong. Adapun metode yang dilakukan untukmenganalisis d a ta a da lah meng gu nakan deskriptif kualitatif.

\section{HASIL DAN PEMBAHASAN}

Program pemberdayaan ini dilakukan untuk membantu meningkatkan perekonomian masyarakat desa Kerongkong yang dilakukan secara terstruktur dan juga melibatkan 
masyarakat secara langsung. Adapun diagram yang menunjukkan alir kerja penelitian pengolahan cabai adalah sebagai berikut:

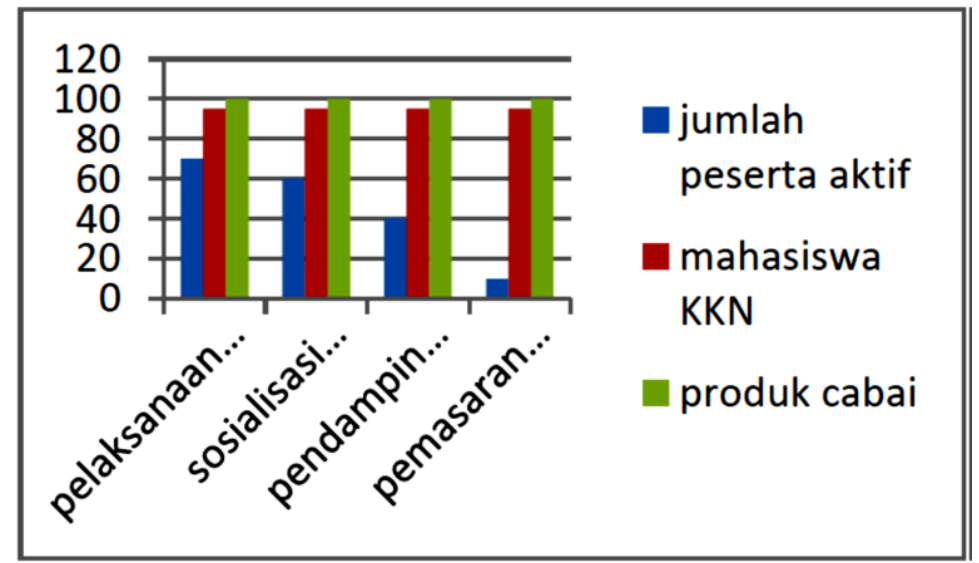

Gambar 2. Diagram Kontribusi Keaktifan Mahasiswa KKN, warga dan produk cabe yang dihasilkan.

Berdasarkan diagram diatas dapat dilihat bahwa masyarakat aktif berpartisipasi dalam kegiatan dengan mahasiswa KKN, namun pada kegiatan terakhir yaitu pada pemsaran jumlah peserta berkurang dikarenakan mahasiswa yang harus lebih aktif dalam kegiatan ini untuk dapat mencari konsumen tetap dan kemudian dilanjutkan oleh masyarakat itu sendiri. Untuk lebih jelasnya adapun tahapan dari kegiatan penelitian ini adalah sebagai berikut:

\section{Pelaksanaan Program Pemberdayaan Masyarakat}

Kegiatan ini diawali dengan melakukan survei terhadap masyarakat setempat. Menurut Singarimbun (1991, p.3) survei yaitu "penelitian yang mengambil sampel dari satu populasi dan menggunakan kuesioner sebagai alat pengumpul data yang pokok". Jadi dapat dikatakan survei merupakan kegiatan mengumpulkan data yang diperlukan untuk keperluan penelitian. Hasil survei menunjukkan bahwa kendala yang dihadapi oleh petani desa Kerongkong berupa kenaikan kargo yang selalu dihadapi setiap tahunnya sehingga menyebabkan harga cabai yang menurun secara drastis. Tahap selanjutnya adalah dilakukan pembahasan program dengan masyarakat setempat yang dalam hal ini berfokus pada ibu-ibu PKK desa Kerongkong.

\section{Sosialisasi dan Pelatihan Pembuatan Sambal Banteng Ngangak}

Sosialisasi pembuatan sambal banteng ngangak dilakukan di tiga dusun Kerongkong yaitu dusun Dayan Bara, Bongkemalik dan Berangkak. Dalam sosialisasi ini dilakukan pengenalan produk sambal banteng ngangak yang akan dibuat di desa kerongkong. Dalam pengenalan ini kami membawa contoh dari sambal yang akan dibuat dalam rangkamembuat masyarakat lebih tertarik terhadap produk ini. Selain itu pula dalam sosialisasi ini dijelaskan mengenai cara pembuatan produk sambal banteng ngangak secara umum dan dirangkaikan dengan penjelasan mengenai cara pemasaran produk serta harga dari produk sambal banteng ngangak. Selanjutnya dilakukannya tanya jawab mengenai produk sambal banteng ngangak dengan masyarakat setempat.

Kegiatan selanjutnya adalah pelatihan pembuatan sambal banteng ngangak. Pelatihan merupakan suatu usaha dalam rangka membina tenaga kerja, yaitu ilmu pengetahuan, keterampilan, dan kemampuan karyawan dalam menjalankan tugas-tugasnya (Hasibuan, 
2001: 116). Kegiatan pelatihan ini dilakukan guna membina masyarakat setempat agar mampu membuat produk seperti yang diinginkan.

Dalam kegiatan ini dilakukan pelatihan pembuatan sambal dengan ibu- ibu PKK sebagai peserta kegiatan. Dalam pelatihan, mahasiswa melakukan peragaan cara membuat sambal banteng ngangak sedangkan peserta melakukan pengamatan atas kegiatan tersebut untuk kemudian dipealajari agar dapat menguasai langkah demi langkah pengolahan.

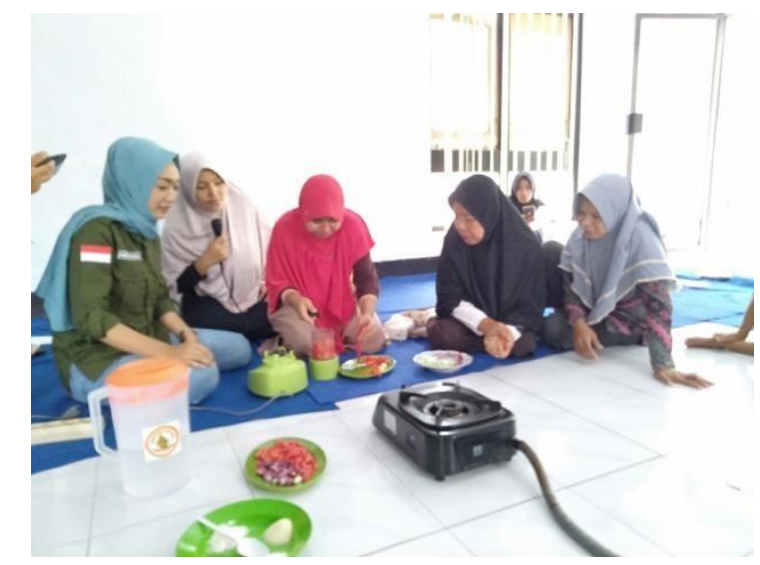

Gambar 3. Kegiatan praktek pembuatan sambal Bangteng Ngangak

\section{Pendampingan Pembuatan Sambal Banteng Ngangak}

Kegiatan ini dilakukan setelah melalui sosialisasi dan pelatihan pembuatan sambal banteng ngangak. Proses pendampingan diharapkan dapat membantu warga belajar dalam proses produksi, pengolahan dan selalu siap apabila produk dibutuhkan (Wulandari:2014). Dalam kegiatan pendampingan, target dari kegiatan ini yaitu ibu-ibu PKK desa Kerongkong membuat langsung sambal banteng ngangak dan hanya didampingi oleh mahasiswa KKN. Sehingga dapat dikatakan bahwa kegiatan ini dilakukan dengan fokus ibu-ibu PKK yang membuat sambal dan hanya didampingi oleh mahasiswa.

\section{Pemasaran Produk Sambal Banteng Ngangak}

Kegiatan ini dilakukan setelah ibu- ibu PKK berhasil membuat produk sambal banteng ngangak sehingga dilakukan pemasaran produk. Pemasaran menurut William J. Stanton, (1984:7) yaitu: "suatu sistem total dari kegiatan bisnis yang dirancang untuk merencanakan, menentukan harga, mempromosikan dan mendistribusikan barang-barang yang memuaskan keinginan dan jasa baik kepada para konsumen saat ini maupun konsumen potensial". Pemasaran produk pertama kali dilakukan dengan memasarkan produk di kalangan masyarakat setempat serta masyarakat Lombok Timur. Kemudian dilanjutkan dengan dilakukannya pemasaran di wilayah yang berbeda dengan target pembeli adalah mahasiswa dan ibu-ibu karir. Untuk meningkatkan tingkat penjualan maka perlu diatur strategi pemasarannya dengan memperluas pemasaran tersebut (Suwastika,2016). Oleh sebabnya dilakukan penjualan ditempat yang berbeda-beda untuk meningkatkan penjualan produk ini.

Di awal penjualan produk sebanyak setengah kilogram telah dihasilkan pembelian sebanyak Rp. 155.000,- sebagai percobaan pemasaran. Setelah dikurangi pengeluaran awal untuk membeli bahan satu kilogram cabai dan satu kilogram bahan penunjang 
sebanyakRp. 75.000,- maka dapat dikatakan bahwa keuntungan dari percobaan pemasaran ini sebanyak Rp. 85.000,- untuk setengah kilogram cabai.

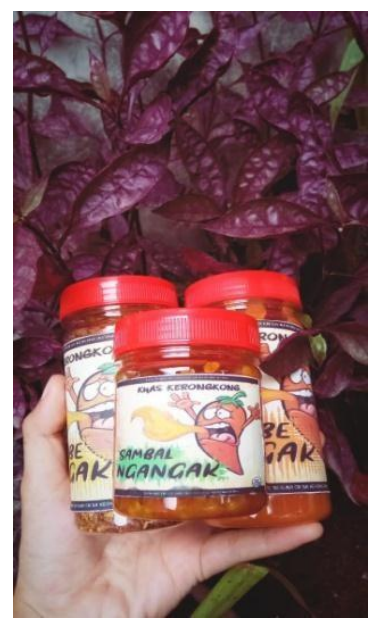

Gambar 4. Produk Sambel Banteng Ngangak

Keuntungan ini akan semakin bertambah apabila pembuatan produkpun ditambah. Penambahan pembuatan produk ini pula dilakukan jika permintaan semakin akan sambal ngangak banteng bertambah.

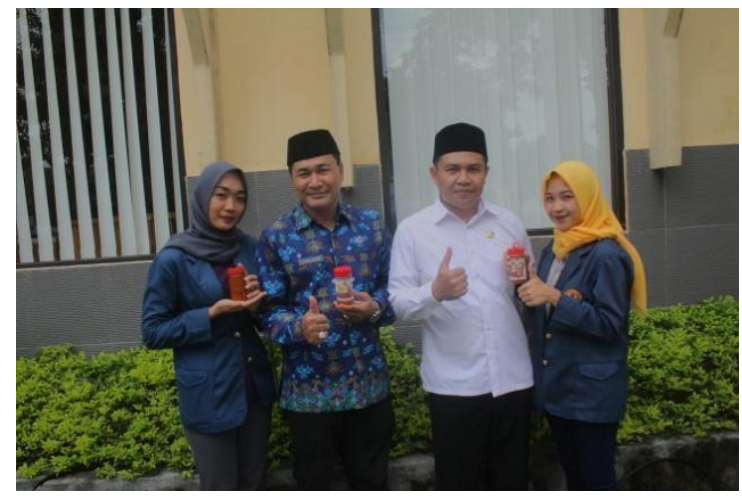

Gambar 5. Promosi produk sambel Banteng Ngangak

\section{KESIMPULAN}

Kesimpulan dari dilakukannya pembuatan sambal banteng ngangak khas Kerongkong ini adalah masyarakat desa kerongkong khususnya ibu-ibu PKK dapat membuat produk tersebut dan dapat menjualkan kembali produk yang telah dibuatnya tersebut. Sehingga dengan berjalannya produk ini akan membantu meningkatkan perekonomian masyarakat setempat terutama petani.

\section{DAFTAR PUSTAKA}

Cahyono, B. 2003. Cabai Rawit Teknik Budidaya Dan Analisis Usaha Tani. Kanisius. Yogjakarta. Hasibuan, 2001.Organisasi dan motivasi.Dasar peningkatan produktivitas.Bumi Aksara: Jakarta. 


\section{J W D}

Jurnal Warta Desa

www.jwd.unram.ac.id

Vol. 1 NO. 1 April 2019

Kilham, C. 2006. Chiles, The Hottest Health Promoters. http://www.medicinehunter.com/He rbsArticles.htm [di akses tanggal 20 Maret 2019]

Rukmana, R., 2002, Usaha Tani Cabai Rawit, Kanisius, Yogyakart

Singarimbun, M.1991. Metode Penelitian, Yogyakarta: LP3S.

Stanton, William J. 1984. Fundamentals of Marketing. 8th Edition. Mc Graw Hill.

Sugiyono.2013. Metode Penelitian Kuantitatif, Kualitatif Dan R\&D.Bandung: Penerbit Alfabeta, CV. Bandung

Suwastika, Iwk.2016. Penentuan Lokasi Pemasaran Produk dengan Menerapkan Metode AHP dan Weighted Product. https://www.ilmuskripsi.com/2016/1 2/jurnal-penentuan-lokasipemasaran.html [di akses tanggal 29 Maret 2019]

Tjandra, E., 2011, Panen Cabai Rawit Di Polybag, Cahaya Atma Pustaka, Yogyakart

Wulandari, A.P.2014. Pemberdayaan Masyarakat Desa Dalam Upaya Peningkatan Kesejahteraan Keluarga Melalui Pelatihan Pembuatan Sapu Gelagah Di Desa Kajongan Kecamatan Bojongsari Kabupaten Purbalingga.Fakultas Hukum.Universitas Negeri Yogyakarta.Yogyakarta. 